A particularly handsome but unpretentious little book is The Guinness Book of Trees (Guinness Superlatives, £4.50). Here, Jeanette and Esmond Harris give a useful summary of the history of trees in Britain from pre-glacial times until the present, and raise a question-mark against the native status usually accorded to the beech and hornbeam. They select 18 conifer and 32 broadleaf trees for full treatment and full-page colour illustration, mostly of high quality and of fine specimens. The order in which the species are presented seems to have no rationale but there is much interesting information about each.

Unfortunately, the maps are a disaster area. That showing the areas of the world from which most exotic species are derived shades the wrong side of South America and even manages to omit California, Oregon and Washington as well as Korea; and the map of tree-collections puts Edinburgh north of Stirling and Oxford in Cambridge. The distribution maps, in bold red and white, even for exotics planted widely, are equally eccentric. Ireland is deprived of grey poplar (the largest specimens in the British Isles are there) and Norway maple, but is covered in English elm. Nonetheless, the line-drawings of foliage are neat and attractive and the book should attract its fair share of buyers.

The International Book of the Forest (Mitchell Beazley/Simon \& Schuster; $£ 14.95, \$ 35$ ) is one of those books of large format and prolific illustration in which information from the text is repeated in boxes and captions, as if to cater for those who cannot face reading the whole tome. The scope in subject, time and region is enormous - from Pangaea through mediaeval forests to modern logging; birds, nocturnal creatures and forest man, to fire and the ecosystem, a single, double-page spread for each. Forest products also take a spread each but while elaborate maps and tables of the world timber trade may have their uses, the details of boat-building and of the manufacture of rubber tyres and plastics are out of place in a book on forests which can spare only a small box for the subject of tree-breeding. The main feature of the book is the surveys of forest types of the world, including the oceanic islands and mangrove swamps, and these include some magnificent photographs.

In complete contrast, as befits its different function, is The Reader's Digest Field Guide to the Trees and Shrubs of Britain (Reader's Digest Association, $£ 6.50$ ), a stoutly bound, attractive book in an unusual broad, shallow format. It is profusely illustrated with mostly good paintings and drawings, and one highquality photograph per page, which last is, however, too small to be of much value. Arranged according to the shape of the leaf, the plants include a wide range of shrubs and yet there is still room for a good selection of trees and some cultivars. A broad ecological slant is given by additional coverage of the wildlife in oak woods, beech woods and other forest types. There are five spreads depicting winter shoots and two on cones, and a small section on some of the places in which to see a variety of trees. Produced to the usual standards of Reader's Digest books, this is a good specimen of the field-guide genre and a reasonable buy.

Alan Mitchell is a Dendrologist with the Forestry Commission and author of a number of books about trees.

\title{
Arboreal splendours and uses
}

\section{Richard Howard}

The Oxford Encyclopedia of Trees of the

World. Consultant editor Bayard Hora. Pp.288. ISBN 0-19-217712-5. (Oxford University Press: 1981.) £12.50, \$19.95.

" ASK a child to draw a tree and he will start with the trunk, then add a fan or brush of branches"'. A straight, woody, selfsupporting trunk, unbranched for a distance from the base, defines a tree at least 21 feet in height to most people. Yet the botanist or the horticulturist may be uneasy with such a definition, which in this book covers ferns (to 80 feet tall), cycads, grasses (bamboo), dragon trees (supposedly 6,000 years old), tree cacti (to $66 \mathrm{feet}$ ), as well as the broadleaved flowering plants and the cone-bearing gymnosperms with needle-like foliage. Trees in cultivation, the primary subjects of this volume, have a history as well as individual beauty and are useful to mankind for their bark, wood, leaves, flowers or fruit.

Thirty-nine authors excel in describing, distinguishing and illustrating the 350 species covered in this volume. The "main" species of large genera are grouped together, with notes on their key characteristics, permitting the reader to identify a plant and to understand the morphological variation within the genus. Useful keys for the identification of trees are provided for conifer families and the conifer genera by families, for the broadleaved families and aberrant genera, and for the broadleaved genera by families for those plants covered in the book. The introductory essays on trunk and wood structure, the forest ecosystem, the forests of the world, and forestry practices and products are instructive evaluations of the economic problems faced by a society which is still dependent on the tree.

The photographs, maps of distribution and drawings are well done, though there are a few exceptions. The photograph of Cornus kousa is a disappointing representation of that handsome flowering tree, and no one would understand the attraction of the American flowering dogwood or the Pacific dogwood from the short, leafy branches used as illustrations here.

The volume is not an "encyclopedia" of trees of the world, as titled, but is certainly a handsome compilation of "trees of many kinds, primarily those grown in Europe'. The treatment of the gymnosperms (conifers) is the best ever published and alone is worth the price of the book. In contrast, the section "Trees of the Tropics"' is atrocious, with errors of fact (e.g. mace, Bertholletia), identification (plate of jackfruit, text on Hura crepitans), and omissions of interesting or important trees (litchi, Blighia), and with a vocabulary inconsistent with the glossary or the other articles. Fortunately it is short and, if ignored, will not detract from what is otherwise an excellent publication.

Richard Howard, formerly Director of the Arnold Arboretum, is Professor of Dendrology at Harvard University.

\section{Anatomy of biology}

\section{Peter R. Scott}

Biology in Profile: $A$ Guide to the Many Branches of Biology. Edited by P.N. Campbell. Pp.128. ISBN hbk 0-08-026846-3; ISBN pbk 0-08-026845-5. (Pergamon: 1981.) Hbk £8, \$19; pbk £3.95, $\$ 9.50$.

WHAT should you tell an intelligent 17-year-old about the biological sciences? How can you convey something of the range of the subject to a bright school-child faced with the many different courses which further education offers? According to the International Council of Science Unions, the proliferation of the biological sciences has now made this task too difficult for any individual to tackle. They have therefore asked a number of distinguished biologists to explain something of their own areas of specialization; the result is this collection of 20 essays. The subjects covered may all be studied at university level, and range from zoology and botany to the less-familiar psychology, endocrinology and biophysics.

The authors were asked to address themselves to intelligent 17-year-olds who are already studying biology. There is no attempt at any consistency of style; some have needed to explain the background to their subject in detail, others have chosen 